\title{
Effect of Dietary Supplementation of Trace Elements on the Growth Performance and Their Distribution in the Breast and Thigh Muscles Depending on the Age of Broiler Chickens
}

\author{
Vladimír Petrovič ${ }^{1}$, Lode Nollet ${ }^{2}$, Gabriel Kováč ${ }^{1}$ \\ ${ }^{1}$ University of Veterinary Medicine and Pharmacy, Clinic of Ruminants, Košice, Slovak Republic \\ ${ }^{2}$ Alltech Netherlands BV, Deinze, Belgium
}

Received June 6, 2009

Accepted January 19, 2010

\begin{abstract}
This study was designed to determine the effects of dietary supplementation of different doses and forms of $\mathrm{Cu}, \mathrm{Zn}, \mathrm{Fe}, \mathrm{Mn}$ and $\mathrm{Se}$ on the growth performance and concentration of these elements in the breast and thigh muscle of Ross 308 broiler chickens at the age of 21, 35 and 42 days. The diets for groups 1 and 2 of birds were supplemented with equivalent amounts of trace elements in an inorganic form ( $\mathrm{Cu}$ sulphate $5 \mathrm{mg} \cdot \mathrm{kg}^{-1}, \mathrm{Fe}$ sulphate, $\mathrm{Zn}$ oxide, Mn oxide $50 \mathrm{mg} \cdot \mathrm{kg}^{-1}$ ), but sodium selenite or selenized yeast (Sel-Plex) were given at the dose of Se 0.3 $\mathrm{mg} \cdot \mathrm{kg}^{-1}$, respectively. Groups 3 and 4 received the same feed as chickens in groups 1 and 2 but with a highly reduced amount of supplemented nutrients in the organic "proteinated" form (Bioplex Cu $2.5 \mathrm{mg} \cdot \mathrm{kg}^{-1}$, Bioplex Fe, Bioplex Zn, Bioplex Mn $10 \mathrm{mg} \cdot \mathrm{kg}^{-1}$ ), except for selenium which was given at the dose of Se $0.3 \mathrm{mg} \cdot \mathrm{kg}^{-1}$ as sodium selenite or selenized yeast (Sel-Plex), respectively. The diet supplemented with the restricted doses of trace elements in proteinated forms $(50 \% \mathrm{Cu}, 20 \% \mathrm{Fe}, \mathrm{Zn}, \mathrm{Mn}$ and a regular level of Se) had the same effect on the indexes of growth performance (such as the body weight on days 1, 7, 14, 21, 28, 35 and 42 of life, total feed intake, feed conversion ratio, carcass yield and abdominal fat of chickens) as well as on the concentration of $\mathrm{Cu}, \mathrm{Fe}, \mathrm{Zn}$ and $\mathrm{Mn}$ (except for Se) in the breast and thigh muscle of broilers at the age of 21, 35 and 42 days as did the diet with the recommended doses of minerals in the form of inorganic salts. Unlike sodium selenite, the proteinated form of Se (selenized yeast) is able to build a significant deposit of this element in the muscle of broilers at the age of 21, 35 and 42 days.
\end{abstract}

Poultry, mineral nutrients, proteinated form, productive indexes, deposition in muscle

There is growing concern how to increase the effectiveness of dietary supplementation of broiler chickens with trace elements on the growth, productive and reproductive performance. The current recommended doses of minerals used in poultry nutrition are taken from the National Research Council documents (Nutrient Requirements for Poultry, 1994) which are based on the results of research conducted in early 1960s and 1970s. Such approach in the nutrition of broilers has the following disadvantages: a) the genetic advancement continually changes the commercial broiler strains, b) inorganic sources of nutrients were routinely used for the dietary supplementation of chickens in those years.

Current experiments on poultry fed with diets enriched with different amounts and forms of $\mathrm{Cu}, \mathrm{Fe}, \mathrm{Zn}, \mathrm{Mn}$ and Se show that the doses of organic "proteinated" forms of elements could be significantly reduced compared to their inorganic forms, without compromising the growth performance of broilers (Peric et al. 2006; Nollet et al. 2007; 2008). It is well known that the use of proteinated forms of trace elements increases their bioavailability for the bird organism (Baker et al. 1987; Fly et al. 1989; Wendekind et al. 1990; Van der Klis and Kemme 2002; Cao et al. 2003; Nollet et al. 2005; Lim et al. 2006; Nollet et al. 2008). The feeding study performed by Leeson (2003) showed that the bioavailability of proteinated forms of elements supplemented to the diet for broilers was at least by $30 \%$ higher than that of inorganic forms of elements. 
On the other hand, negative interactions were found between the inorganic forms of trace elements added to the diet (Du et al. 1996; Modal et al. 2007), probably as a result of the competitive inhibition between them during their absorption. In addition, it was concluded that the body retention of inorganic forms of $\mathrm{Cu}, \mathrm{Fe}, \mathrm{Zn}, \mathrm{Mn}$ and $\mathrm{Se}$ is relatively low (Mohanna and Nys 1998; Van der Klis 1999) and that the excretion of $\mathrm{Cu}, \mathrm{Zn}, \mathrm{Fe}$ and $\mathrm{Mn}$ is significantly higher for the inorganic minerals than for the proteinated forms of elements (Nollet et al. 2007; Leeson and Caston 2008).

This study was designed to determine the effects of dietary supplementation of different doses and forms of $\mathrm{Cu}, \mathrm{Zn}, \mathrm{Fe}, \mathrm{Mn}$ and $\mathrm{Se}$ on the growth performance as well as on the concentration of these elements in the breast and thigh muscle of Ross 308 broiler chickens at the age of 14,28 and 42 days.

\section{Materials and Methods}

Two hundred unsexed Ross 308 broilers, were randomly divided on the day of hatching into 4 groups $(\mathrm{n}=50$ per group) and fed for 42 days with diets containing different amounts and forms of $\mathrm{Cu}, \mathrm{Fe}, \mathrm{Zn}, \mathrm{Mn}$ and $\mathrm{Se}$. The diets were fed ad libitum during the whole experimental period for a healthy development of the broiler chickens. The broiler feed "Starter" was fed for days 1 to 21, the broiler feed "Grower" for days 21 to 35 and the broiler feed "Finisher" for days 35 to 42, respectively. The diets and Bioplex Cu, Bioplex Fe, Bioplex Zn, Bioplex Mn and Sel-Plex were prepared and purchased from Alltech Inc., Belgium. All premixes were fortified with phytase and xylanase and a coccidiostatic preparation (Salinomycin) was mixed into the diets for days 1 to 35 of the broiler's life. The composition of diets fed to the broiler chickens during the entire experimental period is presented in Table 1.

During the whole experiment, the broiler chickens in groups 1 and 2 were fed with the diet supplemented with $\mathrm{Cu} 5 \mathrm{mg} \cdot \mathrm{kg}^{-1} \mathrm{DM}$ (Cu sulphate), Fe, $\mathrm{Zn}, \mathrm{Mn} 50 \mathrm{mg} \cdot \mathrm{kg}^{-1} \mathrm{DM}$ (Fe sulphate, $\mathrm{Zn}$ oxide, Mn oxide) and Se 0.3 $\mathrm{mg} \cdot \mathrm{kg}^{-1} \mathrm{DM}$ in the form of sodium selenite or selenized yeast, respectively. Groups 3 and 4 received the same feed supplemented with a highly reduced dose of trace elements (except for $\mathrm{Se}$ ) in the proteinated forms: $\mathrm{Cu} 2.5$ $\mathrm{mg} \cdot \mathrm{kg}^{-1} \mathrm{DM}$ (Bioplex Cu), Fe, Zn, Mn $10 \mathrm{mg} \cdot \mathrm{kg}^{-1} \mathrm{DM}$ (Bioplex Fe, Bioplex Zn, Bioplex Mn) and Se $0.3 \mathrm{mg} \cdot \mathrm{kg}^{-1}$ DM in the form of sodium selenite or selenized yeast (Sel-Plex), respectively.

On the $1^{\text {st }}$ day of life, the broiler chickens were placed in one-level cages. The lighting regime was 23L:1D

Table 1. Composition of diets fed to the broiler chickens Ross 308 during the entire experimental period

\begin{tabular}{|l|c|c|c|}
\hline Component, g/kg of DM & Starter (day 1-21) & Grower (day 21-35) & Finisher (day 35-42) \\
\hline Wheat & 534.5 & 566.6 & 566.6 \\
\hline Peas & 100 & 100 & 100 \\
\hline Rape seed meal (32\% CP) & 30 & 25 & 25 \\
\hline Soybean meal (46,5\% CP, 1.5\% fat) & 250 & 220 & 220 \\
\hline Palm oil & 25 & 35 & 35 \\
\hline Soya oil & 25 & 25 & 25 \\
\hline Premix ${ }^{\text {a }}$ & 5 & 5 & 11.5 \\
\hline Limestone & 14.5 & 11.5 & 3.5 \\
\hline Monocalcium phosphate & 8 & 3.5 & 0.1 \\
\hline Natuphos 5000G (phytase) & 0.1 & 0.1 & 2.2 \\
\hline NaCl & 2.2 & 2.2 & 2 \\
\hline NaHCO 3 & 2 & 2 & 1.5 \\
\hline L-lysine & 1.5 & 1.5 & 2 \\
\hline DL-methionine & 2 & 2 & 0.6 \\
\hline L-threonine & 0.5 & 0.6 & 5 \\
\hline
\end{tabular}

$1 \mathrm{~kg}$ of basal diet contained: dry matter, $879 \mathrm{~g}$; crude protein, $201 \mathrm{~g}$; crude fat, $73 \mathrm{~g}$; ash, $45 \mathrm{~g}$; crude fibre, 31 ; ME broiler, $12.31 \mathrm{MJ}$; lysine, $11.3 \mathrm{~g}$; methionine, $4.8 \mathrm{~g}$; methionine+cystine, 8.2; threonine, 7.6; tryptophan, $2.4 \mathrm{~g}$; valine, $9 \mathrm{~g}$; arginine, 12.9; histidine, $5 \mathrm{~g}$; Ca, $6.8 \mathrm{~g} ; \mathrm{P}, 4.5 \mathrm{~g} ; \mathrm{Na}, 1.5 \mathrm{~g} ; \mathrm{K}, 8.6 \mathrm{~g} ; \mathrm{Cl}-2 \mathrm{~g} ; \mathrm{Cu}, 10 \mathrm{mg}$; Fe, $150 \mathrm{mg} ; \mathrm{Zn}, 35 \mathrm{mg}$; Mn, $15 \mathrm{mg}$; Se, $0.1 \mathrm{mg}$

aPremix supplied per kg of basal diet: vitamin A, $10000 \mathrm{IU}$; vitamin $\mathrm{D}_{3}, 3000 \mathrm{IU}$; vitamin E, $20 \mathrm{mg}$; vitamin $\mathrm{K}$, $3 \mathrm{mg}$; tiamine, $2 \mathrm{mg}$; riboflavin, $8 \mathrm{mg}$; niacin, $15 \mathrm{mg}$; cholinchlorid, $50 \mathrm{mg}$; pantothenic acid, $50 \mathrm{mg}$; pyridoxine, $5 \mathrm{mg}$; folic acid, $2 \mathrm{mg}$; cyanocobalamin, $30 \mu \mathrm{g}$; biotin, $0.2 \mathrm{mg}$; I, $2 \mathrm{mg}$; Co, $1 \mathrm{mg}$ 
till the end of the experiment. The initial room temperature of $32{ }^{\circ} \mathrm{C}$ was reduced every week by $3{ }^{\circ} \mathrm{C}$ to a final temperature of $22-23^{\circ} \mathrm{C}$. All birds had free access to water and the feed. From the $2^{\text {nd }}$ to the $5^{\text {th }}$ day of age, the chickens received antibiotic (Enroxyl 5\% premix, UNI Biotech) at the dose of $0.5 \mathrm{ml} \cdot \mathrm{l}^{-1}$ and the Newcastle disease vaccine (AVIPEST Lyof., Mevak a.s.) was administered on the $18^{\text {th }}$ day of life. Both preparations were dissolved in drinking water. The protocol was approved by the local Ethics Commitee.

None of the birds in the treatment groups died during the experiment. The average body weight (BW) of broilers in each group was recorded on days 1, 7, 14, 21, 28, 35 and 42 of life. The total feed intake as well as the feed conversion ratio was calculated at the end of the 42 -day experiment. The carcass yield of broilers ( $\%$ of final $\mathrm{BW}$ ) and abdominal fat content (in $\%$ and $\mathrm{g}$ of final $\mathrm{BW}$ ) were determined.

On days 21,35 and 42 of experiment, fifteen broiler chickens were slaughtered by the decapitation. Subsequently, samples of breast and thigh muscle within each group were taken and stored at $-18{ }^{\circ} \mathrm{C}$ till analyzed. After wet mineralization in the microwave oven (Perkin Elmer, MLS 1200), the concentration of copper, zinc and iron in all samples was measured by the flame AAS method and the concentration of manganese was determined by the GFAAS method (Lippo and Sarkela 1995). The concentration of selenium was measured by the same instrument equipped with a hydride generation system according to Bax et al. (1986).

The one-way analysis of variance (ANOVA) with post hoc Tukey's multiple comparison test was applied for the statistical analysis between the treatments on days 21, 35 and 42 of life of broiler chickens. Significant changes were found by paired Student's $t$-test comparing the $1^{\text {st }} v \mathrm{vs} .2^{\text {nd }}$ (day 21 compared to day 35 ) as well as the $2^{\text {nd }}$ vs. the $3^{\text {rd }}$ sampling (day 35 compared to day 42). The statistical software GrafPad Prism, Version 4.00 (2003) was used in both cases.

\section{Results and Discussion}

The diet supplemented with trace elements in proteinated forms that were restricted to $50 \% \mathrm{Cu}, 20 \% \mathrm{Fe}, \mathrm{Zn}, \mathrm{Mn}$ and on the regular level of Se had the same effect on the observed indexes of growth performance as follows: body weight at days 1, 7, 14, 21, 28, 35 and 42 of life, final feed intake, feed conversion ratio, carcass yield and abdominal fat as the recommended doses of inorganic elements (Fig. 1 and Table 2). The addition of trace elements $(\mathrm{Cu}, \mathrm{Fe}, \mathrm{Zn}, \mathrm{Mn}$ and $\mathrm{Se}$ ) in the proteinated form to the diet could be reduced to $33 \%$ of regular levels as compared to the use of their inorganic salts as the feed supplement, without compromising the growth performance of broilers as afore said.

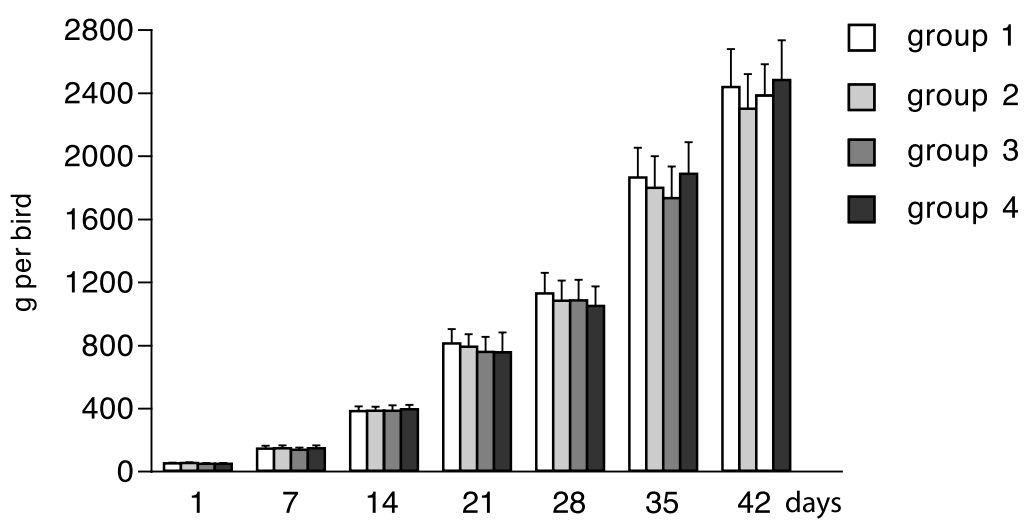

Fig. 1. The effects of dietary supplementation of the different amounts and forms of $\mathrm{Cu}, \mathrm{Fe}, \mathrm{Zn}, \mathrm{Mn}$ and $\mathrm{Se}$ on the body weight of broiler chickens. Values are means \pm S.D.; $n=50$ in all groups of birds at the age of $1,7,14$ and 21 days; $n=35$ in all groups of birds at the age of 28 and 35 days; $n=20$ in all groups of birds at the age of 42 days

The restricted doses of proteinated forms of $\mathrm{Cu}, \mathrm{Zn}, \mathrm{Fe}$ and $\mathrm{Mn}$ (except of Se) supplemented to the diet for broilers had the same effect on the amount of these element in both muscles on the $21^{\text {st }}, 35^{\text {th }}$ and $42^{\text {nd }}$ day of life of broilers as the recommended doses of their inorganic salts (Tables 3 and 4). Moreover, Bao et al. (2007) found no significant 
Table 2. The effects of supplementation of the diet with different amounts and forms of $\mathrm{Cu}, \mathrm{Fe}, \mathrm{Zn}$, $\mathrm{Mn}$ and Se on the growth performance of broiler chickens after slaughter (day 42 of life)

\begin{tabular}{|l|c|c|c|c|}
\hline Index & Group 1 & Group 2 & Group 3 & Group 4 \\
\hline $\begin{array}{l}\text { Final body weight } \\
\text { (g per bird) }\end{array}$ & $2435 \pm 282.7$ & $2297 \pm 204.8$ & $2321 \pm 204.3$ & $2480 \pm 160.8$ \\
\hline $\begin{array}{l}\text { Total feed intake } \\
\text { (g per bird) }\end{array}$ & $3783 \pm 145.5$ & $3907 \pm 122.9$ & $3780 \pm 186.1$ & $3798 \pm 157.3$ \\
\hline Feed conversion ratio & 1.55 & 1.7 & 1.7 & 1.53 \\
\hline Carcass yield (\%) & 74.05 & 74.92 & 73.26 & 74.15 \\
\hline Abdominal fat (g) & $28.7 \pm 9.13$ & $33.9 \pm 12.26$ & $29.7 \pm 15.45$ & $33.6 \pm 8.68$ \\
\hline Abdominal fat (\%) & 1.18 & 1.47 & 1.28 & 1.35 \\
\hline
\end{tabular}

Results are presented as mean $\pm \mathrm{SD}, \mathrm{n}=20$

differences in the concentration of $\mathrm{Cu}, \mathrm{Fe}, \mathrm{Zn}$ and $\mathrm{Mn}$ in the blood plasma and liver of broilers fed with a low-organic diet ( $2 \mathrm{mg}$ of Cu, $20 \mathrm{mg}$ of Fe, $20 \mathrm{mg}$ of $\mathrm{Mn}, 20 \mathrm{mg}$ of $\mathrm{Zn}$ per $\mathrm{kg}$ ), a mid-organic diet (4 mg of $\mathrm{Cu}, 40 \mathrm{mg}$ of Fe, $40 \mathrm{mg}$ of $\mathrm{Mn}, 40 \mathrm{mg}$ of $\mathrm{Zn}$ per $\mathrm{kg}$ ), a high-organic diet ( $8 \mathrm{mg}$ of $\mathrm{Cu}, 80 \mathrm{mg}$ of Fe, $80 \mathrm{mg}$ of $\mathrm{Mn}, 80 \mathrm{mg}$ of $\mathrm{Zn} \mathrm{per} \mathrm{kg}$ ) and an inorganic diet ( $4 \mathrm{mg}$ of $\mathrm{Cu}, 40 \mathrm{mg}$ of $\mathrm{Fe}, 40 \mathrm{mg}$ of $\mathrm{Mn}, 40 \mathrm{mg}$ of $\mathrm{Zn}$ per $\mathrm{kg}$ ).

On the other hand, the amount of copper, manganese and selenium in the breast and thigh muscle of broilers was found to depend on age. In all groups of birds, the amount of zinc and manganese in both muscles was significantly lower $(P>0.05)$ and higher $(P>0.001)$ at the age of 21 days, respectively, than at 35 days. The amount of copper was significantly higher $(P>0.01)$ at the age of 35 days than at 42 days of life. Mondal et al. (2007) found a

Table 3. The effects of supplementation of the diet with different forms and amounts of $\mathrm{Cu}, \mathrm{Fe}, \mathrm{Zn}, \mathrm{Mn}$ and $\mathrm{Se}$ on the concentration of these trace elements $\left(\mathrm{mg} \cdot \mathrm{kg}^{-1} \mathrm{DM}\right)$ in the breast muscle of broiler chickens at the age of 21,35 and 42 days

\begin{tabular}{|c|c|c|c|c|c|}
\hline \multirow{2}{*}{} & \multicolumn{5}{|c|}{ Index } \\
\cline { 2 - 6 } & $\mathrm{Cu}$ & $\mathrm{Fe}$ & $\mathrm{Zn}$ & $\mathrm{Mn}$ & $\mathrm{Se}$ \\
\hline Day 21 & & & & & \\
\hline Group 1 & $1.04 \pm 0.15$ & $4.15 \pm 1.83$ & $4.9 \pm 0.37$ & $0.17 \pm 0.05$ & $0.07 \pm 0.01^{\mathrm{A}}$ \\
\hline 2 & $1.11 \pm 0.28$ & $3.39 \pm 1.05$ & $4.72 \pm 0.36$ & $0.15 \pm 0.01$ & $0.17 \pm 0.04^{\mathrm{B}}$ \\
\hline 3 & $0.96 \pm 0.16$ & $3.01 \pm 1.31$ & $4.68 \pm 0.37$ & $0.15 \pm 0.05$ & $0.07 \pm 0.01^{\mathrm{A}}$ \\
\hline 4 & $0.99 \pm 0.17$ & $3.42 \pm 0.68$ & $4.2 \pm 0.39$ & $0.15 \pm 0.01$ & $0.15 \pm 0.01^{\mathrm{B}}$ \\
\hline Day 35 & & & & & \\
\hline Group 1 & $0.95 \pm 0.23$ & $3.66 \pm 0.72$ & $6.38 \pm 1.34^{*}$ & $0.08 \pm 0.01^{* * *}$ & $0.05 \pm 0.01^{\mathrm{A}}$ \\
\hline 2 & $1.16 \pm 0.31$ & $3.19 \pm 0.68$ & $5.22 \pm 0.73^{*}$ & $0.07 \pm 0.01^{* * *}$ & $0.16 \pm 0.01^{\mathrm{B}}$ \\
\hline 3 & $1.14 \pm 0.22$ & $3.7 \pm 1.21$ & $6.17 \pm 1.91^{*}$ & $0.07 \pm 0.01^{* * *}$ & $0.05 \pm 0.01^{\mathrm{A}}$ \\
\hline 4 & $1.09 \pm 0.15$ & $3.11 \pm 0.63$ & $5.96 \pm 0.66^{*}$ & $0.09 \pm 0.02^{* * *}$ & $0.16 \pm 0.01^{\mathrm{B}}$ \\
\hline Day 42 & & & & & \\
\hline Group 1 & $0.77 \pm 0.17^{*}$ & $3.22 \pm 0.47$ & $5.43 \pm 0.32$ & $0.1 \pm 0.01$ & $0.12 \pm 0.02^{\mathrm{A}^{* * * *}}$ \\
\hline 2 & $0.75 \pm 0.08^{* *}$ & $3.46 \pm 0.82$ & $5.33 \pm 0.31$ & $0.09 \pm 0.02$ & $0.30 \pm 0.02^{\mathrm{B}^{* * *}}$ \\
\hline 3 & $0.76 \pm 0.19^{* *}$ & $3.24 \pm 0.56$ & $5.36 \pm 0.41$ & $0.08 \pm 0.01$ & $0.12 \pm 0.02^{\mathrm{A}^{* * *}}$ \\
\hline 4 & $0.65 \pm 0.12^{* *}$ & $2.91 \pm 0.51$ & $5.4 \pm 0.28$ & $0.09 \pm 0.01$ & $0.26 \pm 0.02^{\mathrm{B}^{* * *}}$ \\
\hline
\end{tabular}

Results are presented as mean $\pm \mathrm{SD}, \mathrm{n}=15$

Significant differences between the experimental groups of broilers at the age of 21,35 and 42 days: ${ }^{x y} P<0.05$; ${ }^{x Y} P<0.01 ;{ }^{X Y} P<0.001$

Significant differences between the related experimental groups in the $1^{\text {st }} \mathrm{vs.} 2^{\text {nd }}$ sampling (day 21 compared with day 35 ) and the $2^{\text {nd }}$ vs. $3^{\text {rd }}$ sampling (day 35 compared with day 42 ): $* P<0.05 ; * * P<0.01 ; * * * P<0.001$ 
Table 4. The effects of supplementation of the diet with different form and amount of $\mathrm{Cu}, \mathrm{Fe}, \mathrm{Zn}, \mathrm{Mn}$ and $\mathrm{Se}$ on the concentration of these trace elements $\left(\mathrm{mg} \cdot \mathrm{kg}^{-1} \mathrm{DM}\right)$ in the thigh muscle of broiler chickens at the age of 21,35 and 42 days

\begin{tabular}{|c|c|c|c|c|c|}
\hline & \multicolumn{5}{|c|}{ Index } \\
\hline & $\mathrm{Cu}$ & $\mathrm{Fe}$ & $\mathrm{Zn}$ & $\mathrm{Mn}$ & $\mathrm{Se}$ \\
\hline \multicolumn{6}{|c|}{ Day 21} \\
\hline Group 1 & $1.12 \pm 0.40$ & $5.56 \pm 0.77$ & $7.73 \pm 0.91$ & $0.18 \pm 0.04$ & $0.09 \pm 0.02^{\mathrm{A}}$ \\
\hline 2 & $1.11 \pm 0.46$ & $5.49 \pm 0.94$ & $8.36 \pm 1.60$ & $0.15 \pm 0.02$ & $0.16 \pm 0.02^{\mathrm{B}}$ \\
\hline 3 & $0.99 \pm 0.17$ & $6.53 \pm 1.57$ & $8.34 \pm 1.07$ & $0.17 \pm 0.03$ & $0.08 \pm 0.02^{\mathrm{A}}$ \\
\hline 4 & $0.96 \pm 0.10$ & $6.33 \pm 1.07$ & $8.45 \pm 1.67$ & $0.15 \pm 0.02$ & $0.16 \pm 0.01^{\mathrm{B}}$ \\
\hline \multicolumn{6}{|c|}{ Day 35} \\
\hline Group 1 & $0.92 \pm 0.10$ & $5.35 \pm 1.92$ & $10.55 \pm 2.49^{* *}$ & $0.11 \pm 0.02^{* * * *}$ & $0.05 \pm 0.01^{\mathrm{A}}$ \\
\hline 2 & $1.08 \pm 0.35$ & $4.34 \pm 1.26$ & $11.62 \pm 2.55^{*}$ & $0.11 \pm 0.01^{* * *}$ & $0.14 \pm 0.02^{\mathrm{B}}$ \\
\hline 3 & $1.10 \pm 0.45$ & $4.96 \pm 1.83$ & $10.90 \pm 2.80^{*}$ & $0.13 \pm 0.02^{* * * *}$ & $0.07 \pm 0.01^{\mathrm{A}}$ \\
\hline 4 & $1.11 \pm 0.29$ & $4.89 \pm 1.25$ & $10.74 \pm 2.10^{*}$ & $0.11 \pm 0.02^{* * * *}$ & $0.14 \pm 0.02^{\mathrm{B}}$ \\
\hline \multicolumn{6}{|c|}{ Day 42} \\
\hline Group 1 & $0.78 \pm 0.11^{*}$ & $6.40 \pm 1.43$ & $10.54 \pm 2.98$ & $0.12 \pm 0.04$ & $0.15 \pm 0.03^{\mathrm{A}^{* * * *}}$ \\
\hline 2 & $0.75 \pm 0.05^{*}$ & $5.42 \pm 1.37$ & $12.05 \pm 2.63$ & $0.11 \pm 0.02$ & $0.21 \pm 0.04^{\mathrm{B}^{* * * *}}$ \\
\hline 3 & $0.74 \pm 0.12^{*}$ & $5.29 \pm 1.37$ & $10.67 \pm 2.21$ & $0.10 \pm 0.01$ & $0.12 \pm 0.02^{\mathrm{A}^{* * * *}}$ \\
\hline 4 & $0.73 \pm 0.07^{* *}$ & $5.85 \pm 1.62$ & $12.19 \pm 2.94$ & $0.12 \pm 0.02$ & $0.28 \pm 0.02^{\mathrm{B}^{* * * *}}$ \\
\hline
\end{tabular}

Results are presented as mean $\pm \mathrm{SD}, \mathrm{n}=15$

Significant differences between the experimental groups of broilers at the age of 21,35 and 42 days: ${ }^{x y} P<0.05$; ${ }^{\mathrm{xY}} P<0.01 ;{ }^{\mathrm{XY}} \mathrm{P}<0.001$

Significant differences between the related experimental groups in the $1^{\text {st }} \mathrm{vs} .2^{\text {nd }}$ sampling (day 21 compared with day 35 ), and the $2^{\text {nd }}$ vs. $3^{\text {rd }}$ sampling day 35 compared with day 42 ): ${ }^{*} P<0.05 ; * * P<0.01 ; * * * P<0.001$

significantly higher concentration of high density lipoprotein cholesterol $(P>0.01)$ on the day 21 of life compared to 42-day-old broilers which could reflect an increased efficiency of the lipid metabolism. Copper and manganese play an important role in the metabolism of lipids in poultry as demonstrated by Bakilli et al. (1995) and Lu et al. $(2006 ; 2007)$, respectively. The significantly increased amount of $\mathrm{Zn}$ in both muscles could reflect its importance in the nuclei acid metabolism and protein synthesis. Our findings of two times faster increase of the body weight in the $3^{\text {rd }}$ phase of life of broilers (from day 35 to 42 of life) compared to the $1^{\text {st }}$ and $2^{\text {nd }}$ phase (from the day of hatching to day 35 of life) indicate that both last mentioned processes are very effective in the last week of the life of broilers.

On the $21^{\text {st }}, 35^{\text {th }}$ and $42^{\text {nd }}$ day, the diet supplemented with selenized yeast significantly increases the concentration of Se in the breast and thigh muscle, contrary to sodium selenite. The apparent advantage of supplementation of poultry feed with the selenized yeast was previously demonstrated by Kuricová et al. (2003), Petrovič et al. (2006), Acamovic and Bertin (2006), Pan et al. (2007). Surprisingly, Wang and Xu (2008) found no significant differences in the muscle Se content in chickens whose diets were enriched with the organic or inorganic form of selenium for 21 days. It is generally supposed that the proportion of selenomethionine (SeMet) escaping metabolism to $\mathrm{H}_{2} \mathrm{Se}$ is incorporated non-specifically into the proteins of striated muscles which represent over $52-56 \%$ of the total body weight in poultry. For this reason the muscle tissue is the most significant body deposit of Se when its proteinated form (selenized yeast naturally containing up to $90 \%$ of total Se in the form of SeMet (Schrauzer 2000)) was given to the diet for poultry rather than sodium selenite. As mentioned above, a characteristic feature of the period between days 35 and 42 of life of broilers is the 
increased anabolism of muscle tissue which could explain the finding of significantly increased amount of Se $(P<0.001)$ in both muscles in this phase of life.

In conclusion, the diet supplemented with trace elements in the proteinated form restricted to $50 \% \mathrm{Cu}, 20 \% \mathrm{Fe}, \mathrm{Zn}$ and $\mathrm{Mn}$ and on the regular level of Se had the same effect on the body weight on days $1,7,14,21,28,35$ and 42 of life, total feed intake, feed conversion ratio, carcass yield and abdominal fat of chickens as well as on the concentration of $\mathrm{Cu}, \mathrm{Fe}, \mathrm{Zn}$ and $\mathrm{Mn}$ (except for $\mathrm{Se}$ ) in the breast and thigh muscle of broilers at the age of 21,35 and 42 days as the recommended doses of inorganic minerals. The results clearly demonstrate that only the proteinated form of Se (selenized yeast) is able to build a significant selenium deposit in the muscle of broilers at the age of 21, 35 and 42 days compared to its inorganic salt (sodium selenite).

\section{Vplyv suplementácie stopových prvkov do diéty na sledované rastové ukazovatele a na ich distribúciu do svaloviny $v$ závislosti na veku broilerových kurčiat}

Štúdia sa zaoberá vplyvom dopĺn̆ania $\mathrm{Cu}, \mathrm{Zn}, \mathrm{Fe}, \mathrm{Mn}$ a Se do diéty na sledované rastové ukazovatele a ich distribúciu v prsnej a stehnovej svalovine broilerových kurčiat Ross 308 vo veku 21, 35 a 42 dní. Diéta pre prvú a druhú skupinu bola suplementovaná rovnakým množstvom anorganických foriem prvkov (síran med'natý $5 \mathrm{mg} / \mathrm{kg}$, síran železitý, oxid zinočnatý, oxid manganistý $50 \mathrm{mg} / \mathrm{kg}$ ), kým Se bol dotovaný ako seleničitan sodný (1. skupina) alebo selenizované kvasnice (2. skupina) v dávke $0.3 \mathrm{mg} / \mathrm{kg}$. Kŕmna dávka pre tretiu a štvrtú skupinu bola tvorená rovnakou bazálnou diétou, ale organické formy stopových prvkov boli podávané v značne redukovaných množstvách (Bioplex $\mathrm{Cu} 2.5 \mathrm{mg} / \mathrm{kg}$, Bioplex Fe, Bioplex Zn, Bioplex Mn $10 \mathrm{mg} / \mathrm{kg}$ ). Selén bol podávaný v rovnakej dávka a formách ako prvým dvom skupinám broilerových kurčiat. Suplementácia redukovaných dávok organických foriem stopových prvkov do diéty pre 3. a 4. skupinu kurčiat mala rovnaký efekt na sledované rastové ukazovatele (živá hmotnost' na 1., 7., 14., 21., 28., 35. a 42. deň, celkový príjem krmiva, konverzia krmiva, výt'ažnost' a abdominálny tuk), ale aj na koncentráciu $\mathrm{Cu}, \mathrm{Fe}, \mathrm{Zn}$ a Mn (okrem Se) v prsnej a stehnovej svalovine broilerových kurčiat vo veku 21, 35 a 42 dní, ako skrmovanie diéty dopĺn̆anej doporučovanými dávkami stopových elementov vo forme anorganických solí (1. a 2. skupina). Na rozdiel od seleničitanu sodného, iba selenizované kvasnice vytvorili významné telové zásoby Se vo svalovine broilerov vo veku 21, 35 a 42 dní.

\section{Acknowledgement}

This work was supported by Grant Agency for Science, VEGA of the Slovak Republic, Grants No. 1/0235/08, and No. 1/0614/09.

\section{References}

Acamovic T, Bertin G 2006: Effects of supra-dietary supplementation of chickens diet with Sel-Ples on selenium deposition in tissues. In Proceedings of Alltech's 22nd Annual Symposium "Nutritional Biotechnology in the Feed and Food Industries". Lexington, KY, USA, p. 8

Baker DH, Halpin KM 1987: Efficacy of manganese-protein chelate compared with that of manganese sulfate for chicks. Poult Sci 66: 1561-1563

Bakilli RI, Pesti GM, Garland WL, Konjufca V 1995: Dietary copper in excess of nutritional requirement reduces plasma and breast muscle cholesterol in chickens. Poult Sci 74: 360-365

Bao YM, Choct M, Iji PA, Bruerton K 2007: Effect of organically complexed copper, iron, manganese, and zinc on broiler performance, mineral excretion, and accumulation in tissues. J Appl Poult Res 16, 448-455

Bax D, Peters FF, Vannoort JPM, Agterdenbos J 1986: The determination of selenium with hydride generation AAS. 2. The role of sodium-borohydride and hydrogen gas. Spectorchim Acta B Atomic Spectrosc 41: 275-282

Cao J, Henry PR, Davis SR, Cousins RJ, Miles RD, Littell RC, Ammerman CB 2003: Relative bioavailability of organic zinc sources based on tissue zinc and metallothionein in chicks fed conventional dietary zinc concentrations. Anim Feed Sci Technol 101: 161-170

Du Z, Hemken RW, Jackson JA, Trammell DS 1996: Utilization of copper in copper proteinate, copper lysine, and cupric sulfate using the rat as an experimental model. J Anim Sci 74: 1657-1663 
Fly AD, Izquierdo OA, Lowry KR, Baker DH 1989: Manganese bioavailability in a Mn-methionine chelate. Nutr Res 9: 901-910

Kuricová S, Boldižárová K, Grešáková L', Levkut M, Leng L' 2003: Chicken selenium status when fed a diet supplemented with Se-yeast. Acta Vet Brno 72: 339-346

Leeson S 2003: A new look at the trace mineral nutrition of poultry: Can we reduced environmental burden of poultry manure? In Nutritional Biotechnology in the Feed and Food Industries. T.P. Lyons and K.A. Jacques, ed. Nottingham Univ. Press, Nottingham, UK.

Leeson S, Caston L 2008: Using minimal supplements of trace minerals as a method of reducing trace mineral content of poultry manure. Anim Feed Sci Technol 142: 339-347

Lim HS, Paik IK, Sohn TI, Kim WY 2006: Effects of supplementation copper chelates in the form of methionine, chitosan and yeast on the performance of briolers. Asian-Aust J Anim Sci 19: 1322-1327

Lippo H, Sarkela A 1995: Microwave dissolution method for the determination of heavy-metals in biomonitors using GFAAS and flame AAS. Atomic Spectrosc 16: 154-157

Lu L, Ji C, Luo XG, Liu B, Yu SX 2006: The effect of supplemental manganese in broiler diets on abdominal fat deposition and meat quality. Anim Feed Sci Tech 129: 49-59

Lu L, Luo XG, Ji C, Liu B, Yu SX 2007: Effect of manganese supplementation and source on carcass traits, meat quality, and lipid oxidation in broilers. J Anim Sci 85: 812-822

Mohanna C, Nys Y 1998: Influence of age, sex and cross on body concentration of trace elements (zinc, iron, copper and manganese) in chickens. Br Poult Sci 39: 536-543

Mondal MK, Das TK, Biswas P, Samanta CC, Bairagy B 2007: Influence of dietary inorganic and organic copper salt and level of soybean oil on plasma lipids, metabolites and mineral balance of broiler chickens. Anim Feed Sci Technol 139: 212-233

National Research Council 1994: Nutrient Requirements for Poultry. Ninth Revised Edition, National Academy Press, National Research Council, Washington, D.C.

Nollet L, Huyghebaert G, Spring P 2008: Effect of different levels of dietary organic (Biolpex) trace minerals on live performance of broiler chickens by growth phases. J Appl Poultry Res 17: 109-115

Nollet L, Van der Klis JD, Lensing M, Spring P 2007: The effect of replacing inorganic with organic trace minerals in broiler diets on productive performance and mineral excretion. J Appl Poultry Res 16: 592-597

Nollet L, Wakerman W, Belyavin C 2005: Replacement of inorganic Cu, Mn, Fe and Zn with Bioplex on growth performance and faecal mineral excretion in broilers. In Proc. 15th Eur. Symp. Poult. Nutr., Balatonfüred, Hungary, p. 173-175

Pan CL, Huang KH, Zhao YX, Qin SY, Chen F, Hu QH 2007: Effect of selenium source and level in hen's diet on tissue selenium deposition and egg selenium concentrations. J Agric Food Chem 55: 1027-1032

Peric L, Nollet L, Miloševic N, Žikic D 2006: Effect of Bioplex and Sel-Plex substituting inorganic trace mineral sources on performance of broilers. Arch Geflügelk 71: 122-129

Petrovič V, Boldižárová K, Faix Š, Mellen M, Arpašová H, Leng L' 2006: Antioxidant and selenium status of laying hens fed with diets supplemented with selenite or Se-yeast. J Anim Feed Sci 15: 435-445

Schrauzer GN 2000: Selenomethionine: A review of its nutritional significance, metabolism and toxicity. J Nutr 130: $1653-1656$

Van der Klis JD 1999: Factors affecting the absorption of minerals from the gastro-intestinal tract of broilers. In Proc. $8^{\text {th }}$ Eur. Symp. Poult. Nutr. WPSA, Bologna, Italy.

Van der Klis JD, Kemmer AD 2002: An appraisal of trace elements: Inorganic and organic. In Poultry Feedstuffs: Supply, Composition and Nutritive Value. J.M. McNab and K.N. Boorman, ed. CAB Int., Wallingford, UK.

Wang YB, Xu BH 2008: Effect of different selenium source (sodium selenite and selenium yeast) on broiler chickens. Anim Feed Sci Tech 144: 306-314

Wedekind KJ, Baker DH 1990: Zinc bioavailability in feed grade sources of zinc. J Anim Sci 68: 684-689 